\title{
ANALISIS FAKTOR RISIKO KEJADIAN TUBERKULOSIS PARU
}

\author{
Gita Sekar Prihanti ${ }^{1}$, Sulistiyawati ${ }^{2}$, Ina Rahmawati ${ }^{3}$ \\ Fakultas Kedokteran, Universitas Muhammadiyah Malang, J1. Bendungan Sutami 188 A Sumbersari malang, \\ Lowokwaru, Kota Malang, 65145, Indonesia, (0341) 582060
}

\begin{abstract}
ABSTRAK
Latar Belakang: Tuberkulosis (TB) merupakan penyakit yang masih menjadi masalah utama kesehatan secara global di dunia dan menyebabkan tingkat morbiditas pada jutaan orang setiap tahunnya. Provinsi Jawa Timur memiliki kasus TB terbanyak kedua pada tahun 2011 dengan kasus mencapai 41.404.Peningkatan infeksi TB tidak luput dari berbagai faktor, yaitu usia, jenis kelamin, status gizi, tingkat kebersihan, ventilasi, suhu, pencahayaan, kepadatan penghuni dan pendidikanTujuan:Mengetahui pengaruh faktor-faktor resiko tehadap kejadian tuberkulosis paru di wilayah Puskesmas Pesantren II Kota Kediri Metode: Menggunakan metode campuran antara kualitatif melalui Focused Group Discussion (FGD) dan kuantitatif,secara observasional analitik dengan desain studi case control. Pengambilan sampel dengan teknik total sampling. Jumlah sampel kasus 33 orang dan sampel kontrol 33 orang.Hasil Penelitian: Hasil uji regresi logistik biner menunjukkan bahwa terdapat delapan variabel yang mempunyai pengaruh signifikan terhadap kejadian TB paru, yaitu $\mathrm{BMI}(p=0,002 ; \mathrm{OR}=8,785 ; \mathrm{CI}=1,153-66,93)$, tingkat pendidikan $(p=0,0026 \mathrm{OR}=2,944 ; \mathrm{CI}=0,183-47,29)$, riwayat imunisasi BCG $(p=0,001 ; \mathrm{OR}=0,048 ; \mathrm{CI}=0,002-1,308)$, riwayat kontak dengan penderita $\mathrm{TB}(p=0,004 ; \mathrm{OR}=13,269$; $\mathrm{CI}=0,737-238,96)$, ventilasi $(p=0,000 ; \mathrm{OR}=0,041 ; \mathrm{CI}=0,001-1,432)$, kepadatan hunian $(p=0,000 ; \mathrm{OR}=0,113$; CI $0,001-1,301)$, sumber air $(p=0,03$; OR $=9,143$; $\mathrm{CI}=0,273-306,7)$, dan riwayat merokok $(p=0,000 ; \mathrm{OR}=11,706$; CI $=0,746-183,66)$. Nilai adjusted $\mathrm{R}$ square menunjukkan bahwa faktor tersebut berpengaruh terhadap kejadian TB paru sebesar $85,9 \%$. Sedangkan faktor yang paling dominan berpengaruh terhadap kejadian TB paru adalah BMI. Kesimpulan:Faktor resiko yang mempengaruhi tingkat kejadian TB meliputi BMI, tingkat pendidikan, riwayat imunisasi BCG, riwayat kontak dengan penderita TB, ventilasi, kepadatan hunian, sumber air dan riwayat merokok.
\end{abstract}

Kata Kunci: TB paru, faktor resiko

\section{ABSTRACT}

Background: Tuberculosis (TB) is a disease that remains a major global health problem in the world and causes morbidity in millions of people each year. East Java Province ranked second bighest number of TB cases in 2011 with the cases reached 41.404. An increased incidence of TB is influenced from various factors, including age, sex, nutritional status, level of bygiene, ventilation, temperature, lighting, occupant density and education.Objective: This study is aimed to determine the influence of risk factors on pulmonary tuberculosis incidence in community health center of Pesantren II Kediri. Methods: This study used observational analytical study with case control study design. Samples were taken with total sampling technique. Total sample of 33 case samples and 33 control samples. Results: The results of binary logistic regression test showed that there were eight variables that have a significant influence on pulmonary tuberculosis incidence, ie BMI ( $\mathrm{p}=0,002 ; \mathrm{OR}=8,785 ; C I=1,153-66,93)$, education level $(\mathrm{p}=0,0026$ OR $=2,944 ; C I=0,183$ 47,29), a bistory of BCG immunization ( $\mathrm{p}=0,001 ; \mathrm{OR}=0,048 ; C I=0,002-1,308)$, bistory contact with TB patients ( $\mathrm{p}=0,004$; $O R=13,269 ; C I=0,737-238,96)$, ventilation $(\mathrm{p}=0,000 ; O R=0,041 ; C I=0,001-1,432)$, population density $(\mathrm{p}=0,000 ; O R$ $=0,113 ; C I$ 0,001-1,301), water resources $(\mathrm{p}=0,03 ; \mathrm{OR}=9,143 ; C I=0,273-306,7)$, and a history of smoking $(\mathrm{p}=0,000$; $O R=11,706 ; C I=0,746-183,66)$. Based on the adjusted R-square value, these factors influence 85,9\% of the incidence of pulmonary tuberculosis. While most dominant factor that influenced the incidence of pulmonary tuberculosis is BMI. Conclusion: the risk factors that influence the incidence rate of TB include BMI, education level, history of BCG immunization, a history of contact with a TB patient, ventilation, residential density, water resources and a history of smoking.

Key words: risk factors, pulmonary tuberculosis.

\section{PENDAHULUAN}

Tuberkulosis (TB) merupakan penyakit yang masih menjadi masalah utama kesehatan secara global di dunia dan menyebabkan tingkat morbiditas pada jutaan orang setiap tahunnya. Tuberkulosis (TB) adalah penyakit infeksi yang disebabkan oleh Mycobacterium tuberculosis (WHO, 2014).

Indonesia sekarang berada pada ranking kelima negara dengan beban TB tertinggi di dunia.Estimasi prevalensi TB semua kasus adalah sebesar 660.000 kasus dan estimasi insidensi berjumlah 430.000 kasus baru per tahun.Jumlah kematian akibat TB diperkirakan 61.000 kematian per tahunnya (Kementrian Kesehatan Republik Indonesia, 2011). Provinsi Jawa Timur memiliki kasus TB terbanyak kedua setelah Provinsi Jawa Barat. Data yang didapat dari Dinas Kesehatan Provinsi Jawa Timur tahun 2011 menunjukkan kasus TB mencapai 41.404 kasus, sementara Jawa Barat mencapai 62.563 kasus(Izza \& Roosiherniatie, 2013). 
Peningkatan infeksi TB tidak luput dari berbagai faktor, yaitu karakteristik individu, lingkungan fisik dan lingkungan sosial di sekitar penderita pasien TB (Manalu, 2010).

Dari data-data di atas kami merasa perlu melakukan penelitian untuk mengetahui faktor-faktorResiko Tehadap Kejadian Tuberculosis Paru Di Wilayah Puskesmas Pesantren II Kota Kediri

\section{METODE}

Penelitian ini bersifat observasional analitik dengan desain case control untuk mengumpulkan data populasi saat ini dan tidak mengambil data masa yang lampau. Penelitian dilakukan di wilayah kerja Puskesmas Pesantren II Kota Kediri yang terdiri dari 6 kelurahan dan penelitian ini berlangsung pada tanggal 07 Desember 2015 sampai dengan 30 Desember 2015. Populasi dalam penelitian ini terbagi menjadi dua yaitu populasi kasus dan populasi kontrol. Populasi kasus adalah seluruh penderita TB Paru yang tercatat di UPK Puskesmas Pesantren sedangkan populasi kontrol adalah warga yang sehat di wilayah kerja Puskesmas Pesantren II. Sampel dipilih menggunakan teknik total sampling.

Sampel dalam penelitian ini berjumlah 33 orang untuk sampel kasus dan 33 orang untuk sampel kontrol. Metode pengumpulan data dalam penelitian ini melalui observasi dan pengambilan data primer menggunakan kuisioner yang telah disiapkan serta berupa data sekunder yang berasal dari status rekam medik..Setelah itu dilakukan pengolahan data.

\section{HASIL}

Telah dilakukan penelitian terhadap populasi yang telah ditentukan. . Data yang diperoleh merupakan data primer yang diambil melalui kuisioner dan data sekunder yang diambil dari status rekam medik.

Berdasarkan tabel 5.1.1 menunjukkan bahwa pada kelompok kasus jumlah responden terbanyak adalah lakilaki sebesar 20 orang $(60,6 \%)$ Sedangkan kelompok kontrol responden terbanyak perempuan sebesar 19 orang (57,6\%).

\begin{tabular}{lcccc} 
Tabel 5. 1. 1 & \multicolumn{2}{c}{$\begin{array}{c}\text { Distribusi Frekuensi Berdasarkan } \\
\text { Jenis Kelamin }\end{array}$} & Kontrol \\
\hline Jenis & \multicolumn{2}{c}{ Kasus } & \multicolumn{2}{c}{ Kontro } \\
\cline { 2 - 5 } Kelamin & Jumlah & $\%$ & Jumlah & $\%$ \\
\hline Laki-Laki & 20 & 60.6 & 14 & 42.4 \\
Perempuan & 13 & 39.4 & 19 & 57.6 \\
\hline \multicolumn{1}{c}{ Total } & 33 & 100 & 33 & 100 \\
\hline
\end{tabular}

Berdasarkan tabel 5.1.2 menunjukkan bahwa pada kelompok kasus maupun kontrol responden lansia paling banyak sebesar 23 orang (69,7\%).

Tabel 5. 1. 2 Distribusi Frekuensi Berdasarkan

\begin{tabular}{lcccc} 
& \multicolumn{2}{c}{ Umur } & \multicolumn{2}{c}{ Kontrol } \\
\cline { 2 - 5 } Usia & \multicolumn{2}{c}{ Kasus } & \multicolumn{3}{c}{ Jumlah } & $\%$ \\
\hline Anak-Anak & 0 & 0.0 & 0 & 0.0 \\
Remaja & 5 & 15.2 & 6 & 18.2 \\
Dewasa & 5 & 15.2 & 4 & 12.1 \\
Lansia & 23 & 69.7 & 23 & 69.7 \\
\hline Total & 33 & 100 & 33 & 100 \\
\hline
\end{tabular}

Berdasarkan tabel 5.1.3 menunjukkan bahwa pada kelompok kasus jumlah responden dengan Body Mass Index (BMI) paling banyak berada pada kategori normal. untuk kelompok kasus sebanyak 17 orang $(51,5 \%)$ dan kasus kontrol sebanyak 23 orang $(69,7 \%)$

Tabel 5. 1. 3 Distribusi Frekuensi Berdasarkan Body Mass Index (BMI)

\begin{tabular}{lrrrr}
\hline \multirow{1}{*}{ BMI } & \multicolumn{2}{c}{ Kasus } & \multicolumn{2}{c}{ Kontrol } \\
\cline { 2 - 5 } & Jumlah & \multicolumn{1}{c}{$\%$} & Jumlah & \multicolumn{1}{c}{$\%$} \\
\hline Underweight & 15 & 45.5 & 3 & 9.1 \\
Normal & 17 & 51.5 & 23 & 69.7 \\
Overweight & 0 & 0.0 & 6 & 18.2 \\
Obese & 1 & 3.0 & 1 & 3.0 \\
\hline Total & 33 & 100 & 33 & 100 \\
\hline
\end{tabular}

Berdasarkan tabel 5.1.4 menunjukkan bahwa pada kelompok kasus jumlah responden terbanyak tingkat pendidikan rendah sebesar 22 orang $(66,7 \%)$. Sedangkan pada kelompok kontrol jumlah responden terbanyak tingkat pendidikan tinggi sebesar 20 orang $(60,6 \%)$.

\section{Tabel 5. 1. 4 Distribusi Frekuensi Berdasarkan Tingkat Pendidikan}

\begin{tabular}{lrrrr}
\hline Tingkat & \multicolumn{2}{c}{ Kasus } & \multicolumn{2}{c}{ Kontrol } \\
\cline { 2 - 5 } Pendidikan & Jumlah & $\%$ & Jumlah & $\%$ \\
\hline Rendah & 22 & 66.7 & 13 & 39.4 \\
Tinggi & 11 & 33.3 & 20 & 60.6 \\
\hline Total & 33 & 100 & 33 & 100 \\
\hline
\end{tabular}

Berdasarkan tabel 5.1.5 menunjukkan bahwa karakteristik tidak bekerja paling banyak pada kelompok kasussebesar 28 orang (84,8\%) sedangkan kontrol paling banyak tidak bekerjasebesar 24 orang (72,7\%).

Tabel 5. 1. 5 Distribusi Frekuensi Berdasarkan Pekerjaan

\begin{tabular}{lrrrr}
\hline Pekerjaan & \multicolumn{2}{c}{ Kasus } & \multicolumn{2}{c}{ Kontrol } \\
\cline { 2 - 5 } & Jumlah & $\%$ & Jumlah & $\%$ \\
\hline Bekerja & 28 & 84.8 & 24 & 72.7 \\
Tidak & 5 & 15.2 & 9 & 27.3 \\
Bekerja & & & & \\
\hline Total & 33 & 100 & 33 & 100 \\
\hline
\end{tabular}

Berdasarkan tabel 5.1.6 menunjukkan bahwa sebagian besar sudah di imunisasi BCG. Pada kelompok kasus jumlah responden yang terdapat skar bekas imunisasi BCG sebesar 19 orang $(57,6 \%)$ dan pada kelompok kontrol jumlah responden yang terdapat skar bekas imunisasi BCG sebesar 31 orang $(93,9 \%)$.

Tabel 5. 1. 6 Distribusi Frekuensi Berdasarkan Riwayat imunisasi BCG

\begin{tabular}{lrrrr}
\hline Riwayat & \multicolumn{2}{c}{ Kasus } & \multicolumn{2}{c}{ Kontrol } \\
\cline { 2 - 5 } Imunisasi & Jumlah & $\%$ & Jumlah & $\%$ \\
\hline Ada Skar & 19 & 57.6 & 31 & 93.9 \\
Tidak Ada & 14 & 42.4 & 2 & 6.1 \\
Skar & & & & \\
\hline Total & 33 & 100 & 33 & 100 \\
\hline
\end{tabular}


Berdasarkan tabel 5.1.7 menunjukkan bahwa pada kelompok kasus jumlah responden yang tidak memiliki riwayat DM sebesar 28 orang $(84,8 \%)$. Sedangkan pada kelompok kontrol jumlah responden yang tidak memiliki riwayat DM sebesar 32 orang $(97,0 \%)$

Tabel 5. 1. 7 Distribusi Frekuensi Berdasarkan Riwayat penyakit DM

\begin{tabular}{lrrrr}
\hline Riwayat & \multicolumn{2}{c}{ Kasus } & \multicolumn{2}{c}{ Kontrol } \\
\cline { 2 - 5 } Penyakit DM & Jumlah & \multicolumn{1}{c}{ Jumlah } & \multicolumn{1}{c}{$\%$} \\
\hline Ada & 5 & 15.2 & 1 & 3 \\
Tidak Ada & 28 & 84.8 & 32 & 97 \\
\hline Total & 33 & 100 & 33 & 100 \\
\hline
\end{tabular}

Berdasarkan tabel 5.1.8 menunjukkan bahwa sebagian besar responden tidak memiliki riwayat kontak dengan penderita TB. Pada kelompok kasus jumlah responden yang tidak memiliki riwayat kontak dengan penderita TB sebesar 20 orang $(60,6 \%)$. Sedangkan pada kelompok kontrol jumlah responden yang tidak memiliki riwayat kontak dengan penderita TB sebesar 30 orang (90,9\%).

Tabel 5. 1. 8 Distribusi Frekuensi Berdasarkan Riwayat kontak dengan penderita TB

\begin{tabular}{lrrrr}
\hline Riwayat & \multicolumn{2}{c}{ Kasus } & \multicolumn{2}{c}{ Kontrol } \\
\cline { 2 - 5 } Kontak & Jumlah & \multicolumn{1}{c}{$\%$} & Jumlah & \multicolumn{1}{c}{$\%$} \\
\hline Ada & 13 & 39.4 & 3 & 9.1 \\
Tidak Ada & 20 & 60.6 & 30 & 90.9 \\
\hline Total & 33 & 100 & 33 & 100 \\
\hline
\end{tabular}

Berdasarkan tabel 5.1.9 menunjukkan bahwa pada kelompok kasus terdapat 22 orang $(66,7 \%)$ dengan ventilasi yang tidak memenuhi syarat. Sedangkan pada kelompok kontrol terdapat 31 orang $(93,9 \%)$ dengan ventilasi yang memenuhi syarat

Tabel 5. 1. 9 Distribusi Frekuensi Berdasarkan Ventilasi Pada Rumah Responden

\begin{tabular}{lrrrr}
\hline \multirow{2}{*}{ Ventilasi } & \multicolumn{2}{c}{ Kasus } & \multicolumn{2}{c}{ Kontrol } \\
\cline { 2 - 5 } & Jumlah & \multicolumn{1}{c}{$\%$} & Jumlah & \multicolumn{1}{c}{$\%$} \\
\hline MS & 11 & 33.3 & 31 & 93.9 \\
TMS & 22 & 66.7 & 2 & 6.1 \\
\hline Total & 33 & 100 & 33 & 100 \\
\hline
\end{tabular}

Berdasarkan tabel 5.1.10 menunjukkan bahwa pada kelompok kasus 23 orang $(69,7 \%)$ dengan kepadatan penghuni yang tidak memenuhi syarat. Sedangkan pada kelompok kontrol terdapat 30 orang $(90,9 \%)$ dengan kepadatan penghuni yang memenuhi syarat

Tabel 5. 1. 10 Distribusi Frekuensi Berdasarkan Kepadatan Penghuni Responden

\begin{tabular}{lrrrr}
\hline Kepadatan & \multicolumn{2}{c}{ Kasus } & \multicolumn{2}{c}{ Kontrol } \\
\cline { 2 - 5 } Hunian & Jumlah & \multicolumn{1}{c}{$\%$} & Jumlah & \multicolumn{1}{c}{$\%$} \\
\hline MS & 10 & 30.3 & 30 & 90.9 \\
TMS & 23 & 69.7 & 3 & 9.1 \\
\hline Total & 33 & 100 & 33 & 100 \\
\hline
\end{tabular}

Berdasarkan tabel 5.1.11 menunjukkan bahwa pada kelompok kasus jumlah responden yang memiliki sumur sebagai sumber air sebesar 30 orang $(90,9 \%)$ sedangkan pada kelompok kontrol jumlah responden yang memiliki sumur sebagai sumber air sebesar 23 orang (69,7\%)

\section{Tabel 5. 1. 11 Distribusi Frekuensi \\ Berdasarkan Sumber Air Di Rumah Responden}

\begin{tabular}{lrrrr}
\hline \multirow{2}{*}{ Sumber Air } & \multicolumn{2}{c}{ Kasus } & \multicolumn{2}{c}{ Kontrol } \\
\cline { 2 - 5 } & Jumlah & \multicolumn{1}{c}{$\%$} & Jumlah & $\%$ \\
\hline Sumur & 30 & 90.9 & 23 & 69.7 \\
PDAM & 3 & 9.1 & 10 & 30.3 \\
\hline Total & 33 & 100 & 33 & 100 \\
\hline
\end{tabular}

Berdasarkan tabel 5.1.12 menunjukkan bahwa pada kelompok kasus jumlah responden yang memiliki tempat sampah di rumahnya sebesar 31 orang $(93,9 \%)$ dan pada kelompok kontrol jumlah responden yang memiliki tempat sampah di rumahnya sebesar 32 orang $(97,0 \%)$

Tabel 5. 1. 12 Distribusi Frekuensi

Berdasarkan Tempat Sampah di Rumah Responden

\begin{tabular}{lrrrr}
\hline Tempat & \multicolumn{2}{c}{ Kasus } & \multicolumn{2}{c}{ Kontrol } \\
\cline { 2 - 5 } Sampah & Jumlah & \multicolumn{1}{c}{$\%$} & Jumlah & $\%$ \\
\hline Ada & 31 & 93.9 & 32 & 97.0 \\
Tidak & 2 & 6.1 & 1 & 3.0 \\
\hline Total & 33 & 100 & 33 & 100 \\
\hline
\end{tabular}

Berdasarkan tabel 5.1.13 menunjukkan bahwa baik pada kelompok kasus maupun kelompok kontrol semua responden tidak memiliki tempat khusus untuk membuang dahak.

Tabel 5. 1. 13 Distribusi Frekuensi Berdasarkan Tempat Khusus untuk Membuang Dahak

\begin{tabular}{lrrrr}
\hline Tempat & \multicolumn{2}{c}{ Kasus } & \multicolumn{2}{c}{ Kontrol } \\
\cline { 2 - 5 } Dahak & Jumlah & $\%$ & Jumlah & $\%$ \\
\hline Tempat & 0 & 0 & 0 & 0 \\
Khusus & & & & \\
Bukan & 33 & 100 & 33 & 100 \\
Tempat & & & & \\
Khusus & & & & \\
\hline Total & 33 & 100 & 33 & 100 \\
\hline
\end{tabular}

Berdasarkan tabel 5.1.14 menunjukkan bahwa pada kelompok kasus jumlah responden yang memiliki tingkat pendapatan rendah sebesar 17 orang $(51,5 \%)$ dan pada kelompok kontrol jumlah responden yang memiliki tingkat pendapatan rendah sebesar 19 orang (57,6\%)

Tabel 5. 1. 14 Distribusi Frekuensi Berdasarkan Tingkat Pendapatan

\begin{tabular}{lrrrr}
\hline Tempat & \multicolumn{2}{c}{ Kasus } & \multicolumn{2}{c}{ Kontrol } \\
\cline { 2 - 5 } Dahak & Jumlah & \multicolumn{1}{c}{$\%$} & Jumlah & $\%$ \\
\hline Rendah & 17 & 51.5 & 19 & 57.6 \\
Tinggi & 16 & 48.5 & 14 & 42.4 \\
\hline Total & 33 & 100 & 33 & 100 \\
\hline
\end{tabular}

Berdasarkan tabel 5.1.15 menunjukkan bahwa pada kelompok kasus jumlah responden yang perokok sebesar 27 orang $(81,8 \%)$. Sedangkan pada kelompok kontrol jumlah responden yang bukan perokok sebesar 20 orang $(60,6 \%)$ 
Tabel 5. 1. 15 Distribusi Frekuensi Berdasarkan Riwayat Merokok

\begin{tabular}{lrrrr}
\hline Tempat & \multicolumn{2}{c}{ Kasus } & \multicolumn{2}{c}{ Kontrol } \\
\cline { 2 - 5 } Dahak & Jumlah & $\%$ & Jumlah & $\%$ \\
\hline Bukan & & & & \\
Perokok & 6 & 18.2 & 20 & 60.6 \\
Perokok & 27 & 81.8 & 13 & 39.4 \\
\hline Total & 33 & 100 & 33 & 100 \\
\hline
\end{tabular}

\section{Analisis Multivariat}

Analisis multivariat bertujuan untuk melihat pengaruh antara beberapa variabel independen terhadap dependen. Adapun hasil pengujian variabel-variabel independen tersebut dengan menggunakan uji regresi logistik biner tampak seperti tabel di bawah ini.

Tabel 5.2 Hasil Analisis Data

\begin{tabular}{|c|c|c|c|c|}
\hline Variabel & $\beta$ & $\mathrm{p}$ & OR & $\mathrm{CI}$ \\
\hline $\begin{array}{l}\text { Jenis } \\
\text { Kelamin }\end{array}$ & - & 0,139 & - & - \\
\hline Umur & - & 0,904 & - & - \\
\hline BMI & 2,173 & 0,001 & 8,785 & $\begin{array}{l}1,153 \\
- \\
66,93\end{array}$ \\
\hline Pendidikan & 1,080 & 0,026 & 2,944 & $\begin{array}{l}0,183 \\
- \\
47,29 \\
\end{array}$ \\
\hline Pekerjaan & - & 0,13 & - & - \\
\hline $\begin{array}{l}\text { Riwayat } \\
\text { Imunisasi } \\
\text { BCG }\end{array}$ & $-3,038$ & 0,001 & 0,048 & $\begin{array}{l}0,002 \\
- \\
1,038 \\
\end{array}$ \\
\hline $\begin{array}{l}\text { Riwayat } \\
\text { DM }\end{array}$ & - & 0,087 & - & - \\
\hline $\begin{array}{l}\text { Riwayat } \\
\text { Kontak TB }\end{array}$ & 2,585 & 0,004 & $\begin{array}{l}13,26 \\
9\end{array}$ & $\begin{array}{l}0,737 \\
- \\
238,9 \\
6 \\
\end{array}$ \\
\hline Ventilasi & $-3,197$ & 0,000 & 0,041 & $\begin{array}{l}0,001 \\
- \\
1,432 \\
\end{array}$ \\
\hline $\begin{array}{l}\text { Kepadatan } \\
\text { Hunian }\end{array}$ & $-2,181$ & 0,000 & - & - \\
\hline Sumber air & 2,213 & 0,03 & 9,143 & $\begin{array}{l}0,273 \\
- \\
306,7 \\
\end{array}$ \\
\hline $\begin{array}{l}\text { Pembuang } \\
\text { an Sampah }\end{array}$ & - & 0,55 & - & - \\
\hline $\begin{array}{l}\text { Pembuang } \\
\text { an Dahak }\end{array}$ & - & 0 & - & - \\
\hline $\begin{array}{l}\text { Pendapata } \\
\mathrm{n}\end{array}$ & - & 0,621 & - & - \\
\hline $\begin{array}{l}\text { Riwayat } \\
\text { Merokok }\end{array}$ & 2,46 & 0,000 & $\begin{array}{l}11,70 \\
6\end{array}$ & $\begin{array}{l}0,746 \\
- \\
183,6 \\
6 \\
\end{array}$ \\
\hline $\begin{array}{l}\text { Adjusted R } \\
\text { square }\end{array}$ & 0,859 & - & - & - \\
\hline
\end{tabular}
3.197 (Ventilasi memenuhi syarat) -2.181 (Kepadatan Hunian memenuhi syarat) +2.213 (Sumber air sumur) +2.460 (Perokok)"

Berdasarkan hasil penghitungan dan persamaan regresi logistik di atas maka menunjukkan bahwa faktor BMI memiliki pengaruh positif terhadap kejadian TB paru, artinya bila BMI seseorang menunjukkan underweight maka akan semakin meningkatkan risikokejadian TB paru. Begitu juga dengan pendidikan rendah, ada kontak TB paru, sumber air sumur, dan perokok memiliki pengaruh positif terhadap kejadian TB paru.Sedangkan Faktor riwayat BCG, ventilasi, dankepadatan hunian menunjukkan pengaruh yang negatif. Hal ini berarti bila ada scar BCG, ventilasi memenuhi syarat, dan kepadatan hunian memenuhi syarat semakin menurunkan risiko kejadian TB paru.

\section{DISKUSI}

Variable BMI mempengaruhi kejadian tuberkulosis paru. Hal ini sesuai dengan penelitian yang dilakukan oleh Misnadiarly tahun 2008 yang menyebutkan bahwa status gizi yang diukur dari BMI memiliki pengaruh dengan kejadian tuberkulosis paru.BMI underweightakan mempengaruhi daya tahan tubuh seseorang sehingga meningkatkan risiko kejadian tuberkulosis paru. Pada penelitian ini, jumlah BMI normal meningkatkan kejadian tuberkulosis parukarena sebagian subjek telah mendapatkan terapi tuberkulosis sehingga berat badan sebagian subjek telah menjadi normal (Misnadiarly, 2008).

Faktor pendidikan mempengaruhi kejadian tuberkulosisHal ini sesuai dengan hasil penelitian yang dilakukan oleh Khandoker, Khan, Kramer, \& Mori tahun 2011. Pendidikan yang tinggi membuat seseorang lebih mudah untuk mengerti pesan mengenai TB.Pada hasil Focussed Group Discussion (FGD) kami ditemukan bahwa sebagian besar responden sudah mengetahui tentang etiologi dan cara penularan serta bagian tubuh yang diserang oleh penyakit tuberkulosis. Hal ini sesuai dengan penelitian oleh Rondags et al, 2014 yang menyatakan bahwa meskipun sebagian besar responden telah mengetahui penyakit TB paling sering menyerang paru-paru namun secara lebih jauh mereka tidak tau etiologi serta cara penularannya(Khandoker, Khan, Kramer, \& Mori, 2011). 
Pada pengetahuan tentang terapi berobat dan kepatuhan berobat, dari hasil FGD yang kami lakukan didapatkan hasil bahwa responden mengatahui lama pengobatan yaitu selama 6-9 bulan.hal ini sesuai dengan penelitian yang dilakukan oleh West, Gadkowski, Truls, Piedrahita, \& Stout, 2008 dimana hasil partisipan dari FGD yang mereka lakukan menjawab jika terapi pengobatan TB adalah selama 9 bulan dan kepatuhan berobat didukung oleh motivasi keluarga.

Riwayat imunisasi BCG mempengaruhi kejadian tuberkulosis. Hal ini sesuai dengan penelitian yang dilakukan oleh John tahun 2001 dan Anita tahun 2006.pemberian BCG dapat meningkatkan pertahanan tubuh terhadap tuberkulosis paru sampai 80\% (Chan PC, 2012).

Variable riwayat kontak dengan penderita tuberkulosis mempengaruhi kejadian tuberkulosis paru.hal ini sejalan dengan Departemen Kesehatan Republik Indonesia, tinggal bersama dengan penderita secara terus-menerus sehingga pada proses ini melalui batuk atau bersin penderita TB Paru positif menyebarkan kiman ke udara dalam bentuk percikan dahak (DepKes, 2008).

Variabel ventilasi mampu mempengaruhi kejadian TB paru. Hal ini sesuai dengan penelitian Lisa tahun 2013. Jumlah dan kualitas ventilasi yang tidak memenuhi syarat kesehatan akan mengakibatkan berkurangnya konsentrasi oksigen dan bertambahnya konsentrasi karbondioksida yang bersifat racun bagi penghuninya, selain itu dapat meningkatkan kelembaban ruangan (Ikeu N, 2007).

Variable kepadatan hunian mempengaruhi kejadian tuberkulosis paru.hal ini sejalan dengan penelitian yang dilakukan oleh Rusnoto et al tahun 2005. Luas bangunan yang tidak sebanding dengan jumlah penghuninya akan menyebabkan overcrowded. Hal ini tidak sehat, sebab disamping menyebabkan kurangnya konsumsi oksigen serta jika salah satu anggota keluarga terkena penyakit infeksi, akan mudah menularkan kepada anggota keluarga yang lain (Soekidjo N, 2003).

Variabel sumber air mempengaruhi kejadian tuberkulosis paru.kualitas sumber air yang menurun dapat menurunkan sistem kekebalan tubuh sehingga mampu memudahkan terinfeksi beberapa penyakit termasuk tuberculosis (Soekidjo N, 2003).

Variabel riwayat merokok mempengaruhi kejadian tuberkulosis paru. Hal ini sesuai dengan penelitian sebelumnya yang dilakukan oleh Lisa pada tahun 2013. Merokok dapat merubah fungsi normal makrofag di alveolus dan imunologi host sehingga meningkatkan resiko infeksi seperti TB paru (Ariyothai N, 2004).

Pada penelitian ini faktor resiko jenis kelamin dan usia tidak memiliki hubungan terhadap kejadian tuberkulosis. Hal ini tidak sesuai dengan penelitian yang dilakukan oleh Hiswani tahun 2004.dikarenakan mayoritas pasien pada negara berkembang seperti Indonesia justru lebih banyak terjadi pada usia produktif dan jumlah total masyarakat usia produktif juga paling tinggi di negara berkembang (Hiswani, 2004).

Faktor resiko pekerjaan tidak memiliki hubungan terhadap kejadian tuberkulosis.Hal ini sesuai dengan penelitian sebelumnya.Jika pasien tidak bekerja maka tingkat social ekonomi juga rendah yang menyebabkan tingkat kesadaran untuk berobat menjadi rendah karena alasan financial (Muaz F, 2014).
Riwayat Diabetes Mellitus tidak memiliki hubungan terhadap kejadian tuberkulosis. Hal ini tidak sesuai dengan penelitian dari Saraswati tahun 20014. Hal ini dapat disebabkan karena hubungan Diabetes Mellitus dengan kejadian tuberkulosis terjadi pada sebagian besar Diabetes Mellitus tipe 1 karena penderita kesulitan mengontrol kadar gula darah (Saraswati LD, 2014).

Variabel tempat pembuangan dahak tidak memiliki hubungan karena semua sampel yang diteliti tidak memiliki tempat khusus untuk membuang dahak.

Pada faktor pendapatan juga tidak memiliki pengaruh yang begitu besar terhadap kejadian tuberkulosis. Hal ini bertentangan dengan hasil penelitian yang dilakukan oleh Ali, Jalilvand dan Hadian. Perbedaan tersebut terjadi akibat ketidakakuratan pasien pada penelitian kami dalam hal pelaporan jumlah pendapatankeluarga yang berpendapatan rendah, Menurut teori pendapatan berhubungan dengan kemiskinan dan lingkungan pemukiman padat kumuh, dimana merupakan tempat ideal untuk perkembangan dan penyebaran kuman tuberkulosis(Gupta D, 2004).

Hasil FGD pada penelitian kami yang berhubungan dengan faktor pendapatan menunjukkan bahwa seluruh responden, tidak ada permasalahan finansial yang menghambat terapi TB karena responden telah mengetahui bahwa obat-obatan TB didapatkan secara gratis. Hal ini tidak sesuai dengan penelitian Rondags et al, 2014 yang menemukan bahwa sebagian besar responden memiliki masalah finansial karena mereka tidak memiliki cukup uang untuk membayar konsultasi dan uang transportasi untuk menuju ke fasilitas kesehatan.

Pada penelitian tentang sikap responden terhadap penyakitnya dan stigma masyarakat terhadap pasien TB didapatkan hasil bahwa sebagian besar responden terbuka tentang penyakitnya terhadap lingkungan sekitarnya dan dari lingkungan sekitarpun juga menerima kondisi pasien dan tidak memberikan stigma negatif. Hal ini berkebalikan dengan penelitian yang dilakukan oleh West, Gadkowski, Truls, Piedrahita, \& Stout, 2008. Masyarakat tidak mau duduk didekat pasien bahkan mereka tidak mau menggunakan alat-alat makan yang sama dengan penderita TB karena mereka beranggapan penyakit TB dapat menular melalui penggunaan alat-alat yang sama serta kontak langsung dengan pasien TB (West, Gadkowski, Truls, Piedrahita, \& Stout, 2008).

Pada penelitian tentang pemilihan tempat pengobatan responden lebih banyak memilih Puskesmas Pesantren II sebagai tempat pemilihan pengobatan. Hal ini tidak sejalan dengan penelitian Rondags, 2014. Mereka memilih untuk berobat di klinik kesehatan pribadi karena mereka percaya bahwa klinik pribadi lebih baik.

\section{KESIMPULAN}

1. Jumlah penderita TB paru di puskesmas Pesantren Kota Kediri yang memenuhi kriteria inklusi sebanyak 33 penderita dan kontrol yang memenuhi kriteria inklusi sebanyak 33 orang.

2. Status karakteristik individu penderita tuberkulosis paru di wilayah kerja Puskesmas Pesantren II Kota Kediri periode 1 Januari - 30 November 2015yang meliputi 
jenis kelamin, usia, Body Mass Index (BMI), pendidikan, pekerjaan, riwayat imunisasi BCG, riwayat Diabetes Mellitus (DM), riwayat kontak dengan penderita TB.

3. Faktor-faktor resiko pada penderita tuberkulosis paru di wilayah kerja Puskesmas Pesantren II Kota Kediri periode 1 Januari - 30 November 2015 meliputi ventilasi, kepadatan hunian, sumber air, tempat pembuangan sampah, tempat pembuangan dahak, pendapatan dan riwayat merokok.

\section{DAFTAR PUSTAKA}

Ariyothai, N. 2004. Cigarette Smoking and Its Relation To Pulmonary Tuberculosis In Adults. Southeast Asian J Trop Med Public Health Hal. 219-27

Chan, PC. 2012. Lower Prevalence of Tuberculosis Infection in BCG vaccinees: a cross- sectional study in adults prison inmates. Original Article.

Depkes. (2008). Laporan Hasil Riset Kesehatan Dasar (Riskesdas) Indonesia. Jakarta: Departemen Kesehatan RI.

Gupta, D. 2004. Role of Socio-Economic Factors in Tuberculosis Prevalence. Indian J Tuberc, 27-31.

Hiswani. (2004). Tuberkulosis merupakan Penyakit Infeksi yang Masih menjadi. Retrieved Desember 9, 2015, from http:/ /library.usu.ac.id

Ikeu, N. (2007). Hubungan antara Karakteristik Lingkungan Rumabdengan Kejadian TB pada Anak di Kecamatan Paseh Kabupaten Sumedang. Bandung: UNPAD.

Izza, N., \& Roosiherniatie, B. (2013, Januari 1). Peningkatan Tuberkulosis di Puskesmas Pacarkeling, Surabaya Tahun 2009-2011. Buletin Penelitian Sistem Kesehatan, XVI, 29. 37.

Kementrian Kesehatan Republik Indonesia. (2011). Terobosan Menuju Akses Universal : Strategi Nasional Pengendalian TB di Indonesia 2010-1014. Kementrian Kesehatan Republik Indonesia, Direktorat Jenderal Pengendalian Penyakit dan Penyehatan Lingkungan . Jakarta: Kementrian Kesehatan Republik Indonesia.

Khandoker, A., Khan, M., Kramer, A., \& Mori, M. (2011). Knowledge about tuberculosis transmission among ever-married women in Bangladesh. The Internasional Journal of Tuberculosis and Lung Disease, 379-84.

Manalu, H. S. (2010, Desember). Faktor-Faktor Yang Mempengaruhi Kejadian TB Paru dan Upaya Penganggulangannya. Jurnal Ekologi Kesehatan, IX(4).

Misnadiarly. (2008). Mengenal, Mencegah, Menaggulangi TB Paru Ekstra Paru. Jakarta: Pustaka Populer Obor.

Muaz, F. 2014. Faktor-faktor yang mempengaruhi Kejadian Tuberkulosis Paru Basil Tahan Asam Positif di Puskesmas Wilayah Kecamatan Serang Kota Serang Tahun 2014. Laporan Penelitian. Fakultas Kedokteran dan Ilmu Kesehatan Universitas Islam Negeri Syarif Hidayatullah Jakarta.

Saraswati, L. D. (2014). Prevalens Diabetes Mellitus dan Tuberkulosis Paru. Jurnal Kesehatan Masyarakat, 192196.

Soekidjo, N. (2003). Ilmu Kesebatan Masyarakat Prinsip-Prinsip Dasar. Jakarta: Rineka Cipta.
West, Gadkowski, Truls, Piedrahita, \& Stout, 2008. Tuberculosis Knowledge, Attitudes, and Beliefs Among North Carolinians at Increased Risk of Infection.. NCMed. vol 69 No 1

World Health Organization (WHO). (2014). Global Tuberculosis Report, Geneva: WHOLibrary. 